УДК 34

DOI $10.21661 / / r-497536$

\title{
Т.И. Корсун
}

\section{КТО ОЦЕНИТ АРЕСТОВАННОЕ ИМУЩЕСТВО ДОЛЖНИКА?}

Аннотация: в статье автор уделяет особое внимание оценке имущества должника в исполнительном производстве. Наличие в аппарате службы судебных приставов специиалистов-оценщиков обеспечит своевременное и качественное исполнение постановлений об аресте, оценке и реализации имущуества с цуелью погашения долга по алиментам, налогам, по кредитам. Автор приходит к заключению, что при использовании изложенных рекомендаций, можно повысить качество работь при оченке имущуества в ходе исполнительного производства и обеспечить баланс интересов долэников, взыскателей, оценщчиков.

Ключевые слова: оченка арестованного имущцества, исполнительное производство, недобросовестная конкуренция, минимальные тарифы, рыночные mapuфbы.

\section{T.I. Korsun}

\section{WHO WILL APPRAISE THE ARRESTED PROPERTY OF A DEBTOR?}

Abstract: in the article the author pays special attention to the assessment of the debtor's property in enforcement proceedings. The presence of experts-appraisers in the law enforcement services will ensure on-time and high-quality execution of warrants of arrest, appraise and sale of property in order to pay off the alimony, taxes, loans. The author comes to the conclusion that the use of these recommendations can improve the quality of work in the appraisal of property in the course of enforcement proceedings and ensure a balance of interests of debtors, collectors, appraisers.

Keywords: appraisal of the arrested property, enforcement proceeding, unfair competition, the lowest rates, market rates.

Оценка имущества должника в исполнительном производстве признана как очень значимый элемент всей системы обращения взыскания долга. Для выбора 
оценочной компании, в целях осуществления оценки арестованного имущества должников в конце каждого года Федеральная Служба Судебных Приставов (ФССП) России в лице территориальных структур в субъектах РФ подают заявки на проведение электронных аукционов. Эта процедура традиционная и призвана определить в конкурентной борьбе на электронных торгах оценщика-исполнителя. Однако, по сведениям электронной торговой площадки Сбербанка, в целом ряде регионов в конце 2018 года торги признаны несостоявшимися по причине отсутствия заявок независимых оценочных компаний. А ведь до недавнего времени проведение всего цикла исполнительного производства обеспечивало баланс интересов судебных приставов и оценщиков.

В чем же причина «развода» интересов этих субъектов и кто в этом виноват? Как нам представляется, причины могут иметь как объективный, так и субъективный характер.

Применительно к реализации законодательства о контрактной системе действия по закупке сопровождаются процедурами, в основе которых заложена свободная конкуренция между участниками. Результаты электронных аукционов обеспечивают не только крупные, но мелкие и средние по суммам массовые сделки по государственным и муниципальным заказам, исполнителями которых являются победители торгов.

В процессе подготовки электронного аукциона на оказание услуг по определению рыночной стоимости арестованного в процессе исполнительного производства имущества должников - физических и юридических лиц, максимальная цена складывается как средняя по запросам 3-5-ти потенциальных поставщиков (участников). В процессе проведения аукциона (торгов) победителем признается участник, предложивший наименьшую сумму. Сумма контракта уменьшается произвольно, при этом сроки, качество исполнения и другие параметры, сформулированные заказчиком, не меняются. Заключенный государственный контракт с таким участником противоречит принципу прозрачности в обосновании цены исполнителя. Мы разделяем мнение специалистов, что государственный контракт с ценой, несоразмерно сниженной победителем электронных 
торгов, является недействительным в силу недобросовестной конкуренции или злоупотребления правом со стороны участника закупки.

Если в ходе мониторинга, аудита и контроля в сфере закупок сделка будет признана необоснованной, органы контроля, указанные в $n .3$ ч. 1 cm. 99 Закона N 44-Ф3, должны выдать предписание об устранении выявленного нарушения и привлечь виновных лиц к административной ответственности (ч. 6 ст. 18 Закона N 44-Ф3) [1].

Таким образом, запрет на недобросовестную конкуренцию является императивно установленным. Об этом же свидетельствуют антидемпинговые меры, предусмотренные в федеральном законе «О контрактной системе государственных закупок», которые направлены на регулирование последствий конкурентной борьбы за право заключить государственный контракт. Так, если при проведении аукциона участником закупки, с которым заключается государственный контракт, предложена цена на двадцать пять и более процентов ниже начальной (максимальной) цены, контракт заключается только после предоставления таким участником обеспечения в полтора раза превышающем размер, указанный в документации о проведении аукциона. Наряду с этим вместо повышенного денежного обеспечения такого участника законом предусмотрено предоставление информации, подтверждающей его добросовестность [1]. Указанные условия заключения государственного контракта рассчитаны на свободную конкуренцию участников закупки.

Если же «победитель» снизил цену исполнения государственного контракта на 75-80\%, такая мера обеспечения недостаточна. В этих случаях целесообразно представить независимое аудиторское заключение, подтверждающее правомерность исполнения обозначенного в контракте объема товаров, работ, услуг по зафиксированной аукционной комиссией цене. Рекомендация была предложена автором еще пять лет назад [2]. Но практического воплощения не получила.

Из новых дополнений в федеральный закон №44-Ф3 можно отметить ужесточение сроков оплаты заказчиками отработанных контрактов, что крайне актуально для правоприменительной практики: до 30 дней, а с малым бизнесом - 
не более 15 рабочих дней с даты подписания заказчиком документа о приемке выполненных работ, услуг [ 3 ]. Для примера, сроки выплаты по отработанным контрактам с ФССП России в территориальных подразделениях растягиваются на пять-шесть и более месяцев после выполнения оценочными компаниями всех условий контракта без последствий для заказчиков. В новой редакции закона предусмотрен штраф для должностного лица заказчика от 30 тыс. до 50 тыс. руб. За повторное нарушение могут дисквалифицировать на срок от года до двух лет [3].

И все же меры финансового порядка не препятствуют безудержному падению цен на торгах. Не останавливает участников торгов перспектива оказаться в реестре недобросовестных поставщиков на определенный период в случае отказа от невыгодного контракта. В практике используется ротация фирм-участников: вместо «засвеченной» как недобросовестный поставщик открывается и регистрируется «чистая».

В Законе №44-Ф3 «О контрактной системе государственных закупок» незыблемым остается право Заказчика не менять объявленной цены контракта в ходе аукциона, поставщики азартно торгуются за право получить государственный контракт. Механизма остановить торг на разумном уровне цен нет. В практике не единичны случаи падения цен на 90-95\% от максимальной. В итоге «победитель» получает контракт, по существу, невыгодный по цене, заказчик - непредсказуемый по качеству и срокам исполнения. Экономия бюджетных средств иллюзорная.

Наглядными примерами служат контракты по обеспечению общественного питания в школьных, дошкольных, лечебных заведениях. Низкая цена выигранного контракта оборачивается низким качеством закупленных продуктов питания. В связи с этим поднимается вопрос переноса конкурентной борьбы потенциальных поставщиков в разряд открытого конкурса, который позволил бы отдать предпочтение качеству поставляемых товаров. В какой-то мере это относится к выбору медицинских препаратов, оборудования и т. д. Перечень товаров, работ, услуг остается открытым. 
Меня как практикующего специалиста не оставляет идея найти и предложить механизм ограничения уровня падения цены в процессе торгов. Например, используя принцип рулетки, компьютер выберет уровень, ниже которого участники не смогут «упасть». При этом победителем будет участник, на котором сработает авторегулятор. Заранее о сумме не будут знать ни заказчик, ни один из участников. Для этого потребуется система алгоритмов, техническую сторону могут обеспечить математики-программисты [4].

Правовая сторона этой процедуры не безупречна. Включение «рулетки» в запрограммированном варианте могут обеспечить операторы электронной площадки, которые имеют статус участников наряду с заказчиками и поставщиками, каждый из них наделен правом добросовестного исполнения своих обязанностей, не мешая нормальной конкурентной борьбе за право заключения контракта. При этом выигрывают все: заказчики получают вменяемого поставщика, поставщик - контракт с ценой ниже максимальной на умеренную величину, бюджет экономит средства на разумном ценовом варианте получения запланированных товаров, работ, услуг. Такая мера, по нашему мнению, направлена на пресечение недобросовестной конкуренции без злоупотребления правом в ходе проведения электронных торгов [4]. Однако предложенное направление не нашло поддержки в правоприменительной практике, в то же время значительно усилилась критика положений закона о контрактной системе в части недобросовестной конкуренции на торгах.

По нашему убеждению, модель привлечения оценочных компаний для определения рыночной стоимости арестованного имущества посредством электронных аукционов себя исчерпала.

Этот неутешительный вердикт подтверждается анализом тарифной политики при заключении государственного контракта по результатам электронного аукциона. Практика участия в торгах свидетельствует, что тарифы - достаточно слабое звено в системе исполнительного производства. На торгах тарифы вынужденно снижаются на 60-70\% от начальной максимальной величины, 
в расчете на то, что оценочная компания получит за свои услуги мизерные, но гарантированные суммы из бюджета.

Действительно, большая часть оценочных услуг в исполнительном производстве оплачивается из бюджета, при этом тарифы не покрывают реальных затрат оценочных компаний, которые включают множество затратных процедур. Это выезд на место хранения (нахождения) объекта оценки, фотографирование, сбор правоустанавливающих документов, запрос в компетентные органы об информации, характеризующие техническую сторону: техпаспорт на жилые и нежилые помещения, выписку из кадастра, запрос в ГИБДД о транспортных средствах, на оборудование - технический паспорт, сертификация и т. д. И только при наличии всего пакета документов специалист-оценщик составляет отчет о рыночной стоимости арестованного объекта, в соответствии с требованиями федерального закона «Об оценочной деятельности в Российской Федерации» [5].

На все описанные процедуры по регламенту исполнительного производства отводится 10 дней [6]. И времени на исполнение и денег на оплату услуг явно недостаточно.

Вместе с тем, должник или взыскатель, не согласные с величиной рыночной стоимости имущества в отчете оценщика, имеют право оспаривать ее, начиная судопроизводство против службы приставов и оценочной компании. При этом за судебную экспертизу они оплачивают эксперту сумму на порядок выше (15000-30000руб.), чем по контрактному тарифу.

Как свидетельствуют результаты судебных разбирательств, при расхождении на 10-15\% от суммы оценки независимого эксперта и оценщика-специалиста по контракту суд присуждает все расходы и судебные издержки к погашению оценочной компанией.

Эта мера не выдерживает никакой критики: получив из бюджета за оценку арестованного, например, автомобиля 1575 руб., оценочная компания должна исполнить судебное решение по погашению издержек на пересмотр его рыночной стоимости 30000-35000руб. Из этого следует, что привлечение оценочной компании по государственному контракту невыгодно не только оценщикам, 
но и в конечном итоге - приставам, поскольку суд отменяет акт продажи этого имущества и возвращает дело на пересмотр.

Нам представляется, что введение минимальных тарифов на осуществление оценочной деятельности оправдано для оценщиков из государственных учреждений, или оценки имущества государственных / муниципальных организаций

В связи с этим вполне привлекательны предложения о создании при УФССП России (на территориях) оценочных групп, с привлечением штатных оценщиков-специалистов. Штатные работники, знающие особенности рынка движимого и недвижимого имущества на своей территории, мобильны для выезда на осмотр и идентификацию объектов. В этих условиях сам процесс сбора информации и составления отчета о рыночной стоимости значительно быстрее и качественнее, а выбор аналогов в этой зоне более обоснован.

В случае привлечения оценщиков из частных фирм их услуги по оценке отдельных категорий арестованного имущества должны оплачиваться по рыночным тарифам.

Следовательно, тарифы на оценочные услуги должны быть дифференцированы не только в зависимости от видов имущества и статуса должника, а также принадлежности оценщиков к государственным или частным структурам.

Из этого следует, что назрела необходимость изменить модель взаимосвязи ФССП России и оценочных компаний.

В исполнительном производстве должниками являются физические лица, индивидуальные предприниматели (ИП), коммерческие и муниципальные организации. На практике Управления приставов в подавляющем большинстве арестовывают имущество физических лиц, и только незначительную часть - имущество юридических лиц: акционерных обществ, обществ с ограниченной ответственностью. Государственного и муниципального имущества в исполнительном производстве практически нет, хотя тарифы на оценочные услуги априори предназначены для оценки государственного (муниципального) имущества. 
В связи с этим целесообразно использовать услуги оценщиков по государственному контракту по минимальным тарифам только для оценки государственного (муниципального) имущества с их оплатой из бюджета.

Не теряет актуальности предложение о создании в Управлениях группы штатных оценщиков, которые будут получать зарплату из бюджета и выполнять порученный объем работ в установленные сроки и надлежащего качества.

Я уверена, что наличие в аппарате службы судебных приставов специалистов-оценщиков наряду с приставами-исполнителями обеспечит своевременное и качественное исполнение постановлений об аресте, оценке и реализации имущества с целью погашения долга по алиментам, налогам, по кредитам.

Одновременно предусмотреть участие специалистов-оценщиков по договору с УФССП России в территориальных подразделениях по рыночным тарифам, которые дают возможность покрыть затраты на проведение оценки и взыскиваются непосредственно с должников: физических лиц или коммерческих организаций.

Считаем целесообразным адресовать рекомендации по изменению порядка проведения оценки в рамках исполнительного производства Министерству юстиции РФ и Федеральному агентству по управлению государственным имуществом, а также Федеральной службе судебных приставов России. Предлагаем выработать тарифы, в соответствии с которыми будет оплачиваться труд штатных оценщиков из государственных учреждений по оценке арестованного имущества, или оценки государственного/ муниципального имущества по государственному контракту с победителями электронных аукционов.

Одновременно предусмотреть ФССП России регламент участия специалистов - оценщиков по договору с территориальными подразделениями для оценки арестованного имущества физических лиц и коммерческих организаций по рыночным тарифам, используя форму запроса котировок, как более простую и недорогостоящую для определения поставщиков услуг. 
Изложенные рекомендации направлены на повышение качества работы при оценке имущества в ходе исполнительного производства и для обеспечения баланса интересов должников, взыскателей, оценщиков.

\section{Список литературы}

1. Федеральный закон от 05.04.2013 №44-Ф3 «О контрактной системе в сфере закупок товаров, работ, услуг для обеспечения государственных и муниципальных услуг» // СПС «Консультант Плюс».

2. Корсун Т.И. Аудит в сфере закупок - норма законодательства о контрактной системе государственных закупок // Правовые системы современности в условиях международной интеграции: материалы 9-й Международной научнопрактической конференции (Ялта, 26-27 сентября 2014 г.). - Ялта, 2014.

3. Правовые новости. О контрактной системе в сфере закупок товаров, работ и услуг для обеспечения государственных и муниципальных нужд. Обзор изменений системы государственных закупок // СПС «Консультант Плюс».

4. Корсун Т.И. О пределе злоупотребления правом участниками контрактной системы государственных закупок //Юридический вестник - 2017. -№3. C. $30-35$.

5. Федеральный закон от 29.07.1998 №135-Ф3 «Об оценочной деятельности в Российской Федерации» // СПС «Консультант Плюс».

6. Федеральный закон от 02.10.2007 №229-Ф3 «Об исполнительном производстве» // СПС «Консультант Плюс».

\section{References}

1. Federal'nyi zakon ot 05.04.2013 44-FZ "O kontraktnoi sisteme v sfere zakupok tovarov, rabot, uslug dlia obespecheniia gosudarstvennykh i munitsipal'nykh uslug". SPS "Konsul'tant Plius".

2. Korsun, T. I. (2014). Audit v sfere zakupok. Pravovye sistemy sovremennosti v usloviiakh mezhdunarodnoi integratsii. Ialta. 
3. Pravovye novosti. O kontraktnoi sisteme v sfere zakupok tovarov, rabot i uslug dlia obespecheniia gosudarstvennykh i munitsipal'nykh nuzhd. Obzor izmenenii sistemy gosudarstvennykh zakupok. SPS "Konsul'tant Plius".

4. Korsun, T. I. (2017). O predele zloupotrebleniia pravom uchastnikami kontraktnoi sistemy gosudarstvennykh zakupok. Iuridicheskii vestnik, S. 30.

5. Federal'nyi zakon ot 29.07.1998 135-FZ "Ob otsenochnoi deiatel'nosti v Rossiiskoi Federatsii". SPS "Konsul'tant Plius".

6. Federal'nyi zakon ot 02.10.2007 229-FZ "Ob ispolnitel'nom proizvodstve". SPS "Konsul'tant Plius".

Корсун Тамара Ивановна - кандидат экономических наук, профессор кафедры финансового и административного права, ФГБОУ ВО «Ростовский государственный экономический университет (РИНХ)», Ростов-на Дону, Россия.

Korsun Tamara Ivanovna - candidate of economical sciences, professor at the of financial and administrative law department, FSFEI of HE «Rostov State University of Economics», Rostov-on-Don, Russia. 